\title{
AYURLOG
}

National Journal of Research in Ayurved Science

http://www.ayurlog.com

June- $2020 \mid$ Volume $08^{\text {th }} \mid$ Issue: $3^{\text {rd }}$

ISSN: $2320-7329$

\section{Role of Mustadi Yapana Basti and Shashtishali Pindasweda in Sub Acute Combined Degeneration (S.A.C.D.) - A Case Study} Gade Shivani Vilas*1, Kulkarni Rajan.B. ${ }^{2}$, Kulkarni Eknath G. ${ }^{3}$, Rathod Sanjivani N. ${ }^{4}$

1-M.D.( Scholar), 2-H.O.D. and Professor, 3-Associate Professor, 4- Assistant Professor,

Department of Kaychikitsa, A.S.S. Ayurved Mahavidyalaya \& Arogyashala Rugnalaya, Ganeshwadi, Panchavati, Nashik, Maharashtra, India.

*Corresponding Author: shivanigade49@gmail.com ; 9689489156

\section{Abstract:}

S.A.C.D. is a nutritional deficiency disorder mainly caused by deficiency of Vit. B12. Its deficiency causes demyelination of posterior, lateral, column and peripheral nerve involvement. So that in this condition we see neurological symptoms such as loss of muscle tone, loss of power, loss of sensation for temperature, touch, pain. If this condition is not treated then it causes severe systemic function loss. Supplement of Vitamin B12 and physiotherapy is the only treatment for this disorder. And it may take 6 to 12 months to get recover. And in long term patients neurological damage may not improve.

According to Ayurveda, if we don't know the name of the disease but we can treat it according to vitiated Dosha and Dushya, Hetu etc.
So S.A.C.D. can be treated as Dhatukshyajanya Vatavyadhi. According to this patient was treated with Mustadi Yapana Basti and Shashtishali Pindasweda and considerable relief from symptoms was observed in the patient within 15 days.

Keyword: S.A.C.D., Mustadi Yapana Basti, Shashtishali Pindasweda, Dhatukshyajanya Vatavyadhi

\section{Introduction:}

SACD is not directly described in ayurvedic samhita but it can be correlated with Dhatukshayajayna vata vyadhi. As described in Charak Samhita though you don't know the name of Vyadhi but you can treat it on its hetu prakupita dosha dushya etc. In presenting case patient was obese and on dieting i.e Unshana, Vyayama, Virudhanna sevan, are main hetus for Vataprakopa. And which leads to 
mandagni and asardhatu formation. So it is treated as Dhatukshyajanya vatavyadhi . रोगा ये अपि अत्र नोद्दीष्टा बहुत्वान्नामरुपात।...Ch.Chi.30/291

In SACD we get symptoms like- unable to walk without support, loss of sensation for temperature, touch and pain, loss of motor functions, muscle gets flabby, muscle tone gets diminished, superficial reflexes gets lost due to involvement of postero lateral column of spinal cord, sensory motor activities gets diminished. According to principle described in Charak Samhita treatment was planned as per Vatavyadhi Chikitsa. And considering the kshaya of Mansa Dhatu mainly. Yapana basti and Pindasweda gives strength to Dhatus. After the treatment given for 15 days as Mustadi yapana basti and Shastishali pinda sweda, we observed marked decrease in symptoms.

\section{AIM AND OBJECTIVES:}

\section{Aim:}

- To study the Ayurvedic management of Sub Acute Combined Degeneration of spinal cord.

\section{Objective:}

1. To study the effect of Mustadi Yapan basti

2. To study the effect of Shashtishali Pindasweda
3. To study the Sub Acute Combined Degeneration (S.A.C.D.) in details according to modern view and Ayurvedic view

\section{Materials and Methods :}

\section{A case report}

Presenting case study is a successful Ayurvedic management of S.A.C.D. i.e.

A 20 year old female patient came with complaints of Difficulty in walking, Numbness of both lower extremities, Loss of sensation at fingers of both foot, Low back ache, Unable to hold footwear, Pain in calf muscle ...Since 2 months. Patient was not having any medical history. On examination reflexes were normal of upper limbs, Romberg sign was present, high stepping was present. In lower limb, Muscle tone - Flaccid (hypotonia),PowerDiminished, muscle wasting was absent, in co- ordination- Snesory atarxia present, snesory system i.e. touch, temperature and pain- Glove and Stocking sign was present at lower limb. Reflexes of Upper limb were normal. While lower limb reflexes Planter, Ankle jerk and deep jerk were absent. Patient came with investigations (MCV-111.1 RBC morphologyAnisocytos, macrocytic, normochromic , Sr.Iron- 340 ug/dl, Sr.TIBC-342ug/dl, Iron saturation $-9.94 \%$, Ferritin-40.81mg/dl, Vit B12- $165.23 \mathrm{pg} / \mathrm{dl}$ and MRI brain- it reveals left Upper limb and both lower 
limb is s/o generalized symmetric severe sensory motor axonal type of peripheral neuropathy) and diagnosis as Sub acute combined degeneration of spinal cord. History of present illness: patient was having symptoms since 2 months. Patient had taken injection vitamin B12 before 2 months still patient is not having improvement, so came for Ayurvedic management.

Hetu: Anashana, Virudhannasevana, Ativyayama,

Purvaroopa: Tingling of lower limb,

Roopa: Unable to walk. Power diminished of lower limb, Muscles gets flabby of foot, loss of sensation for temp, pain at foot.

Dosha: Vata

Dushya: Ras, Rakta, Mansa ,Meda.

Sthana: Lower limb.

Nidana: Dhatukshyajanya vatavyadhi.

Treatment was given as follows:

\section{Shaman chikitsa}

1) Ekangvir ras $120 \mathrm{mg} B D$ after meal

2) Dashamoola rishta $20 \mathrm{ml} \mathrm{BD}$ Anupana Jal after meal

Panchakarma :

1) Mustadi yapan basti: prepared according to the procedure of ksheerpaka Kalpana

First Matra basti of Til taila was given then 5 continuous mustadi yapana basti where given in next 5 days and on 7 th day Anuvasana basti was given.
2) Shashtishali Pindasweda is done for 7 days from kati to paad. During the course of basti.

This procedure was repeated after 7 days as earlier.

\section{Observation:}

After completing course of Mustadi Yapana basti for 14 days along with Shashtishali pinda sweda, we observed that symptoms were decreased. Due to Shashtishali pindasweda, muscle tone was increased. Patient was able to walk without support. Pain in calf muscle was reduced. Patient was able to hold footwear. Patient was having sensation for temperature, pain and pressure.Where all these things were unable to do on first day. There was remarkable improvement in symptoms.

\section{Result:}

Mustadi yapan basti along with shashtishali pinda sweda, is effective to recover fast from S.A.C.D. symptoms.

\section{Discussion:}

Sub Acute Combined Degeneration of spinal cord i.e. S.A.C.D. is not described in our classical texts. But we treated the disease according to dosha-dushya, hetu, samprapti etc. as said by Acharya Charka. As the name is given as Dhtukshyajanya Vatavyadhi on the basis of vitiated Vatadosha and Rasa, Rakta, Mansa and Meda as dushya. Shamana Chikitsa and Panchakarma is also selected according to 
our Ayurvedic diagnosis. As Basti is treatment for Vatadosha we selected Yapana basti which can be given for long duration also. Also Pindasweda was selected which strengthen Dhatus and gives relief from pain. As described in Charak Samhita Yapan basti acts as Shukra, Mansa, Balajanana.Yapan basti is Sadya Baljanana Rasayana.

\section{Conclusion:}

In presenting case study,on the basis of Ayurvedic principles S.A.C.D. was correlated with Dhatukshyajyanya Vatavyadhi and treated accordingly. And treatment like Mustadi Yapana basti and Shashtishali Pindsweda is significant in treating S.A.C.D. This study shows that diagnosis and treatment done according to our Ayurvedic principles is effective.

\section{Acknowledgement:}

Special thanks to Department of Kaychikitsa and Department of Panchakarma. A.S.S. Ayurved Mahavidyalaya \& Arogyashala Rugnalaya, Ganeshwadi, Panchavati, Nashik, Maharashtra, India.

\section{References:}

1. Book Brian R. Walker, Nicki R. Colledge,Stuart H. Ralston,Ian D. Penman Davidson's principles and practice of medicine, 22nd edition,
London Churchill Livingstone, 2014, Page No.1024,1025 and 1026.

2. Vaidya Yadavji Trikamji Aacharya, Charak Samhita, Chakrapanivirchit Ayurved Deepika vibhushita, Varanasi, Chaukhambha Surbharti Prakashan, Edition- 2017 Chikitsasthana, Adhyaya 30, Verse No 291,Page no.645 and 646.

3. Vaidya Yadavji Trikamji Aacharya, Charak Samhita, Chakrapanivirchit Ayurved Deepika vibhushita, Varanasi, Chaukhambha Surbharti Prakashan, Edition- 2017, Sidhisthana, Adhyaya 12, Verse No16(1),Page no.731.

4. Vaidya Yadavji Trikamji Aacharya, Charak Samhita, Chakrapanivirchit Ayurved Deepika vibhushita, Varanasi, Chaukhambha Surbharti Prakashan, Edition- 2017, Sidhisthana, Adhyaya 12, Verse No16(1),Page no.731.

5. Vaidya Yadavji Trikamji Aacharya, Charak Samhita, Chakrapanivirchit Ayurved Deepika vibhushita, Varanasi, Chaukhambha Surbharti Prakashan, Edition- 2017, Sutrasthana, Adhyaya 18, Verse No44-47,Page no.108.

6. Dr. Vasant C. Patil, Principles and Practice of Panchakarma, Varanasi, Chaukhambha Sanskrit Sansthana, Reprint 2017, Chapter No.9, Page No-206-2011.

\section{Cite this article:}

"Role of Mustadi Yapana Basti and Shashtishali Pindasweda in Sub Acute Combined Degeneration (S.A.C.D.) - A Case Study."

Gade Shivani Vilas, Kulkarni Rajan.B., Kulkarni Eknath G., Rathod Sanjivani N. Ayurlog: National Journal of Research in Ayurved Science- 2020; (8) (3): $01-04$ 